\title{
Model of Local Oriented Business Network - Strengthening Efforts Competitiveness of Tourism Small, and Medium Enterprises (SME's) in Disruption Era
}

\author{
Rochiyati Murniningsih', Yulinda Devi Paramita ${ }^{2}$, Eni Zuhriyah ${ }^{3}$ and Friztina Annisa ${ }^{4}$ \\ \{rochiyati.murni@ummgl.ac.id ${ }^{1}$ \} \\ ${ }^{1}$ Department of Management, Universitas Muhammadiyah Magelang, Magelang, Indonesia \\ ${ }^{2,3,4}$ Department of Accountant, Universitas Muhammadiyah Magelang, Magelang, Indonesia
}

\begin{abstract}
This paper describes and analyses the performance of local-oriented business networks for tourism SME's. The study was conducted at the Temanggung Regency Tourism SME's in Central Java Indonesia. Temanggung has many tourism objects and is potentially crucial for improving the welfare of the community. However, in disruption era - challenges faced by SME's Tourism are getting heavier. SME's internal problems and the phenomenon of invisible competitors. The study of this local-oriented business networking model will be able to synergize the various potentials and strengths that exist in tourism SME's so that it can strengthen the competitiveness of SME's.
\end{abstract}

Keywords: Business network local oriented, competitiveness, tourism

\section{Introduction}

The tourism sector is one of the main driving sectors of economic growth in the research area. The growth of this sector has fostered Micro, Small and Medium Enterprises (SME's) in the tourism industry which has great potential as a means of alleviating poverty. This potential can be achieved through a strengthening of the SME's business network that will enhance social interaction and economic transactions that rely on the tourism sector (Muhammad Al Azhari, 2018). Researchers assume that by examining business network patterns, it will be able to synergise various potentials and strengths of SME's, to strengthen capital, production processes and also in marketing SME products (Murniningsih, 2017). Furthermore, efforts to enhance the SME's business network will become a breakthrough in improving the national economy.

On the other hand, although there is an essential role in the tourism sector in the regional economy, the benefits and benefits of the tourism sector have not yet been felt in the lower layers of society (Sosa, Roy and Bautista, Adriana, 2015). Therefore, the involvement of local communities as tourism businesses. This requires local communities to be more active and creative in utilizing the tourism potentials in their area. (O'Regan and Ghobadian, 2005) Especially in rural areas. This is because rapid development concerning infrastructure and technology makes people saturated and longs for the calm that can be obtained from nature. So that tourism by developing the concept of life in the countryside can be an alternative. 
The rapid development of tourism is also related to the existence of SME's in a disruptive era (Azisah, Siti, 2018). Factors driving the development of the tourism sector include the development of information technology, the advancement of transportation technology, free-market growth, the revolution in processing technology, the liberalization of the tourism and trade industry. Likewise, each region has different potential, due to differences in economic conditions, natural resources, the size of the area and the size of the population. This allows each region to give a different emphasis on developing the potential of the region, including tourism potential (Omerzel and Kregar, 2016). The tourism industry that can be a source of regional income is the community-owned tourism industry/community tourism development - CTD (Gill, 2010).

This condition was responded by the local community in Temanggung Regency, by seeing that in the area had a lot of natural potentials that could be developed as a tourism destination. The tourism industry network consists of hotels/inns / home stays, restaurants/catering services, tourism businesses (tourism objects, souvenirs, art performances), business travel services (travel agents, tour guides). The development of business networks conducted by local communities (SME's) is the initial strategy for developing tourist attractions (Dirgiatmo, 2015). The involvement of local communities, in this case, encourages the occurrence of multiplier effects from the existence of a tourist attraction (Rashid, 2014) (Ngugi, 2013). This will promote the creation of new jobs and support regional development.

Most of the Temanggung Regency area is highlands and mountains, which is part of the Dieng Plateau series. Temanggung Regency has many natural attractions scattered in Temanggung Regency consisting of, Posong, Kledung Pass, Walitis Forest, and 4 beautiful waterfalls or waterfalls namely Curug Trocoh, Curug Lawe, Curug Thitang, and Curug Onje. In Kabupaten Temanggung, artificial tours were also developed namely Pikatan Water Park, multi-dimensional rides in the form of a 4-dimensional cinema with a movie ride simulator, Kartini Park, Kali Progo Park, Pengayoman Park, Alun-Alun, Meteorite Monument, and Bambang Sugeng Monument. The cultural tourism in Temanggung Regency is Pringapus Temple, Gondosuli Inscription, Suran Traji, Ki Ageng Makukuhan Tomb, and recently discovered Liyangan Site (Santoso and Rais, 2015).

Temanggung Regency, is a district in Central Java Province, precisely at the foot of Mount Sumbing and Mount Sindoro. Most of this district is a plateau with cool air. Temanggung District is well-known as the best tobacco producing district in Indonesia. Tobacco is a commodity that is expected to boost the economic life of the community. This condition is due to the most significant money circulation in this district is when the tobacco harvest season arrives. However, the length of the chain of tobacco trade arrangements and the absence of price standardization are the main problems that cause the life of the people of Temanggung Regency to be far from what is expected. There were still 87.8 thousand people or $12.32 \%$ of the total population of Temanggung Regency were poor people (BPS Jawa Tengah, 2017). The concept of tourism development should be more pro-poor and lead to poverty alleviation efforts. This is known as Pro-Poor Tourism (Ashley et al., 2001). Referring to the concept, tourism is used as an alternative effort to alleviate poverty because this sector can play an essential role in the absorption of employment opportunities and the 
empowerment of micro businesses in high numbers in the regions (Varraa et al., 2012). Local governments have also optimized virtual marketing which is expected to attract more consumers through the OVOP (one village one product) program. This phenomenon is at the same time exciting to analyze, how tourism SMEs respond to the disruption era (Mason, G., Rincon-Aznar, A, and Venturini, 2017)

\section{Research Methodology}

The approach used in this study is a qualitative approach. Qualitative research methodology is scientific research that aims to understand a phenomenon in a social context naturally by prioritizing the process of interaction of deep communication between researchers and the phenomenon under study (Denzin, Norman K and Lincolyn, 1994). Qualitative methodologies are able to explore a deep understanding of specific organizations or events rather than describe the surface part of a large sample of a population. This is in accordance with the research that will be conducted in order to understand the conditions of social interaction in terms of institutions that occur in Temanggung Regency tourism SME'S actors. Data collection was conducted interviews, forum group discussion, observation, and documentation. Data interpretation methods use four stages (Miles, Huberman, Saldaña, Johnny, 1984), namely: (1) data collection, (2) data reduction, (3) data presentation, and (4) conclusion drawing. To test the validity of the data, it was tested by triangulating both sources (from different informants) and techniques (using different data collection techniques). The unit of analysis in this study was 80 tourism SMEs in Temanggung Regency. Meanwhile, the informants were the Temanggung Regency SME'S from administrators, the Office of Industry and Trade, the Tourism Office, the sub-district apparatus related to the economic development of the community.

\section{Result \& Discussion}

In analyzing business networking models, it can be categorized into three stages of development as follows:

\subsection{Fragmented Program}

At this stage, SME's actors are more concerned with their own business, the most important thing is to generate income for their families and groups. SME's have not been integrated into SME association containers (Omerzel and Kregar, 2016). In the end, often unhealthy competition emerges, so that large investors will annex small investors. For example, in Tlahap Village, Kledung Subdistrict, SME'S in several tourism objects around Posong are often "left behind" during the tobacco season. The results of the forum group discussion show that there is a lack of professionalism among tourism SME'S actors. Residents are less interested, because this business cannot promise his life, even there has been mastery of this business by large investors. The role of the government as a congested state, where the government intervenes and controls SME's (Philip Alford \& Stephen John Page, 2015). This can be seen from the programs of capital assistance or equipment, 
exhibitions for SMEs from the local government through various agencies such as Industries, Trade and Cooperative Services, Social Services, Labour and Transmigration, and others. However, from the results of the forum group disccusion, it is known that regional device organizations often overlap activities. The distribution of access to training and the acquisition of assistance for SME'S actors is also less efficient (LeenaAarikka-Stenroos1Jaakkola, 2012). There are a number of SME's involved in training and assistance activities in several events, but there are SME's who do not have access to the government at all. This means that assistance is less coordinated and integrated, so that the driving force of strengthening the competitiveness of SMEs becomes less optimal (Ashley et al., 2001). Not infrequently, aid is also misused into unproductive expenditures, resulting in bad credit and stagnation in business development.

At this stage, strengthening actors among SME'S actors is more directed at increasing their production. As a result the development of SME'S actors leads to certain groups that have various advantages, such as capital, tenacity and adequate human resources that can develop well. Conversely, actors who lack capital, skills and tenacity cannot develop, as a result, many government assistance programs are not well targeted. As a result, in this development, there is a fragmentation of plans, goals, processes, containers, and activities of SME's. In this case, SME's are separated with weak bargaining positions, both in the supply of raw materials, production, and marketing of SME's products. This condition is more than $40 \%$ occurring in Temanggung Regency, meaning that most SME's actors are not yet coordinated and integrated, and institutionalized in a container. From the forum group disccusion results, it is known that several groups of SME's are still there, but the conditions are dead.

\subsection{Integrated Program}

In this stage SME'S must already have a single association. All production and marketing process programs are managed by associations, resulting in harmonization between SME'S actors and synergies in the face of the market (Endi Rekarti, 2017). Thus the group approach has been well institutionalized, marked by a routine forum, the existence of a board, the existence of a development program, and also has a constitution and by-laws for the dynamics and development of the SME'S group (Al Azri, 2013). The role of the government to be a regulator for SME's, in this case through legal products etc. Legal products that regulate and serve as the basis for SME's in carrying out their roles. Then the policy of the organization of the regional apparatus should be local government work unit policy must follow. Institutional strengthening of SMEs by building networks internally continues. For this reason, the need for SME groups is one of them is ongoing assistance, before the aid program is launched to SMEs. One of the needs of actors other than capital is knowledge about entrepreneurship and wider market access. The Temanggung Regency Trade \& Cooperative Service also provides programs and assistance to tourism SME'S groups. Group approaches can be used as controls for individuals belonging to groups (Nuryakin, Vincient Didiek Wiet Ariyanto, 2018). The formation of SME groups at this stage has been based on the awareness of members who feel the need to form a forum for efforts to improve their business, both short-term, long-term and sustainable. From the results of observation, the formation of 
SME'S groups is still based on the need to seek assistance, whether it is a program of Regional Economic Development, a program from group of farmer, a program from joint bussiness group, and several other regional government assistance programs. Tourism SME'S groups in Temanggung district already have groups based on product similarities.

\subsection{Networking Program}

In this model, SME'S has independence (Rovindo. 2017,) Products have explored the domestic and global markets. The SME'S model in Temanggung District has not arrived at this stage. From the results of the forum group discussion, almost all SME'S players still need capital, equipment and skills. At this stage, the role of the government is as a facilitator, because SME'S actors are already strong enough, and ready to play a role without government assistance (Nedim Yüzbaşıŏglu Pınar ÇelikYunusTopsakal, 2014). Even in its development, the SME'S actors have been able to contribute to regional income. Arabica coffee SME'S with the aroma of tobacco already exports, although the network does not yet exist in the stage of independence (Tourism Industry Aotearoa, 2017).

Based on the results of the forum group discussion with tourism SME'S actors in Temanggung District, several important roles were formulated in strengthening the business network as follows:

Table 1: Temanggung Regency Tourism SME's Business Network Performance

\begin{tabular}{ll}
\hline \multicolumn{1}{c}{ Subject } & \multicolumn{1}{c}{ Role } \\
\hline $\begin{array}{l}\text { Local } \\
\text { government }\end{array}$ & $\begin{array}{l}\text { the regional government facilitates partnerships between the government, } \\
\text { business people and non-government institutions }\end{array}$ \\
\hline SME'S & SME's applies a strategy to strengthen business networks \\
\hline Third Party & $\begin{array}{l}\text { Local partners from the private sector help exploit the opportunity of the } \\
\text { region to develop policies and strategies that are appropriate to local needs. }\end{array}$ \\
College, & \\
NGO) & \\
\hline
\end{tabular}

A good business network is very important to build trust and confidence in network partners so they want to share core competitive resources (Stuart Read, Nicholas Dew, Saras D. Sarasvathy, Michael Song, 2009). Otherwise, the relationship will be full and ambiguous without benefits among network partners (Hitt et al., 2009; Walter et al., 2006). Relational skills are important for companies to create and maintain long-term relationships with mutual benefits among participating companies. Kale et al. (2000) refer to relational skills as social competencies, which are very important for relationship management because relationships are often situations of interpersonal exchange (Awuah, 2001). It is said that the situation of interpersonal exchange relies on trust and confidence built by partners where partners with well-placed relational skills instill both problems of trust and confidence in the second party. The relational skills include such aspects as "communication skills, problem solving skills, interpersonal skills, conflict management skills, empathy, emotional stability, self-reflection, a 
sense of justice and cooperation" (Greg W. Marshall, Daniel J. Goebel, and William C. Moncrief, 2003).

A good business network will also strengthen the capabilities of SME's in this disruptive era. There are three things that SME'S must do to deal with the disruption era:

a. Digitality: SME's are required to be able to open themselves to the development of alldigital communication and information technology today. On the other hand, SME's must also be able to utilize digital tools as a medium for strengthening competitiveness

b. Creativity: SME's must create services that give satisfaction to customers. Creativity can also create a value proposition (superior value) on the products they produce.

c. Connectivity: the ability of SME's in building relationships with as many people as possible, both directly and through social media. Good connectivity, this will be an opportunity for us to build a stronger network.

SME's that have good relational skills are very likely to develop effective and sustainable relationships that are mutually beneficial among network partners. Furthermore, this will increase competitive advantage (Teece, 2007). Basically, there are two categories of social networking: inter-company social networks that are important in acquiring new knowledge and corporate social networks that involve networking between workers in the same company. This business network is very important for the dissemination of strategic information from outside the company and strengthened the company's knowledge base. In this view, both social networks are essential for acquisition, exchange, and utilization of resources and learning new capabilities that are important for the company's competitive advantage that is needed for corporate performance (Kale, Dyer \& Singh., 2002).

\section{Conclusion}

a. From the results of the study, it is known that most tourism SME'S players agree on the importance of local oriented business networks in the production process, provision of raw material needs and also in the marketing of SME'S products. But to build a strong business network requires the involvement of various parties, such as government facilitation, assistance from universities or non-governmental organizations, assistance from CSR and the commitment of SME's themselves to form networks among business actors.

b. Need to integrate programs for SME's from all regional device organizations (OPD). The integration of this program will improve the effectiveness of strengthening the competitiveness of tourism SME's.

c. Increasing the role of government as an adhesive for tourism SME'S networks with universities, Non-Governmental Organizations, CSR. This role will improve the capability of SME's to face the disruptive era.

\section{Acknowledgment}

This paper is part of the PDUPT funded by the Ministry of Research Technology and Higher Education, Republic of Indonesia. The researchers also thanked the Head and Staff of 
the Department of Tourism of Temanggung District, Departement of Trade \& Industry of Temanggung District.

\section{Reference}

[1] Ashley, C. et al. (2001) 'Pro-Poor Tourism Strategies : Expanding Opportunities for the Poor Implementing PPT Strategies'.

[2] Azisah, Siti, 2018 (2018) 'Building Indonesia's s Micro Small and Medium Enterprise :', (August). doi: 10.2991/icaaip-17.2018.20.

[3] Al Azri, H. I. (2013) 'Modeling the marketability of Tourism Small Businesses Oman's experiences', ProQuest Dissertations and Theses, p. 202. Available at: http://ezproxy.msu.edu/login?url=http://search.proquest.com/docview/1508837417?acc ountid $=12598 \% 5 \mathrm{Cnhttp} / / /$ za2uf4ps7f.search.serialssolutions.com/?ctx_ver=Z39.882004\&ctx enc=info:ofi/enc:UTF8\&rfr_id=info:sid/ProQuest+Dissertations $+\&+$ Theses+Global\&rft_val_.

[4] BPS Jawa Tengah, 2017 (2017) 'Propinsi Jawa Tengah Dalam Angka', 8(2), pp. 224 237.

[5] Denzin, Norman K and Lincolyn, Y. V. S. (1994) Introduction, Entering The Field of Qualitative Research. London: University Colleges London. Available at: http://stlss.ucl.ac.uk/course-materials/PUBLGC32_50089.

[6] Dirgiatmo, Y. (2015) 'Analysis of the Potential Use of Social Networking for the Success of Strategic Business Planning in Small and Medium-Sized Enterprises', Mediterranean Journal of Social Sciences, 6(2). Available at: http://www.mcser.org/journal/index.php/mjss/article/view/6098.

[7] Endi Rekarti, C. M. D. (2017) 'Improving business performance: A proposed model for SMEs', European Research Studies Journal, 20(3), pp. 613-623. Available at: https://www.researchgate.net/publication/319458652_Improving_business_performanc e_A_proposed_model_for_SMEs.

[8] Gill, S. (2010) 'Tourism Development in Local Communities: As a Community Development Approach', 6(2), pp. 155-161.

[9] Greg W. Marshall, Daniel J. Goebel, and W. C. M. (2003) 'No Title', Journal of Business Research, 2003, vol. 56, issue 4, 247-255, vol 56(issue 4), p. Hiring for success at the buyer-seller interface. Available at: https://econpapers.repec.org/article/eeejbrese/v_3a56_3ay_3a2003_3ai_3a4_3ap_3a24 7-255.htm.

[10] LeenaAarikka-Stenroos1ElinaJaakkola (2012) 'Value co-creation in knowledge intensive business services: A dyadic perspective on the joint problem solving process', Industrial Marketing Management, 41(1). Available at: https://doi.org/10.1016/j.indmarman.2011.11.008.

[11] Mason, G., Rincon-Aznar, A. and Venturini, F. (2017) 'Which skills contribute most to absorptive capacity, innovation and productivity performance? Evidence from the US and Western Europe', the Centre for Learning and Life Chances in Knowledge Economies and Societies. Available at: http://www.llakes.ac.uk. 
[12] Miles, Huberman, Saldaña, Johnny, 1984 (no date) 'Qualitative Data Analysis'.

[13] Muhammad Al Azhari (2018) 'Embracing the New Era of Tourism', Globe Asia.

[14] Murniningsih, R. dkk (2017) 'Membangun Daya Saing UMKM Melalui Kapabilitas Relasional Solutif \& Desain Lokal Akulturatif'.

[15] NedimYüzbaşığluPınarÇelikYunusTopsakal (2014) 'A Research on Innovation in Small and Medium-sized Enterprises in Tourism Industry: Case of Travel Agencies Operating in Antalya', Procedia - Social and Behavioral Sciences, 153, pp. 735-743. Available at: https://doi.org/10.1016/j.sbspro.2014.09.039.

[16] Ngugi, I. K. (2013) 'Relational capabilities for value co - creation and innovation in SMEs', Journal of Small Business and Enterprise Development, 17(2), pp. 260-278.

[17] Nuryakin, Vincient Didiek Wiet Ariyanto, M. B. S. (2018) 'Mediating effect of value creation in the relationship between relational capabilities on business performance', Contaduría y Administración, 63(1), pp. 1-21. Available at: https://doi.org/10.22201/fca.24488410e.2018.1178.

[18] O'Regan, N. and Ghobadian, A. (2005) 'Innovation in SMEs: the impact of strategic orientation and environmental perceptions', International Journal of Productivity and Performance Management. Emerald, 54(2), pp. 81-97. doi: $10.1108 / 17410400510576595$.

[19] Omerzel, D. G. and Kregar, T. B. (2016) 'Networking in the Tourism Industry: The Case of Three Neighbouring Mediterranean Tourism Destinations Umrežavanje u turizmu: Slučaj triju susjednih mediteranskih turističkih destinacija', pp. 66-72. doi: 10.17818/NM/2016/2.5.

[20] Philip Alford \& Stephen John Page (2015) 'Marketing technology for adoption by small business', The Service Industries Journal, 35(11-12), pp. 655-669.

[21] Rashid, M. M. (2014) 'an Analysis on Characteristics and Performance of Tourism Related Smes in Lenggong Valley, Perak', p. 38.

[22] Santoso, K. I. and Rais, M. N. (2015) 'Implementasi Sistem Informasi Geografis Daerah Pariwisata Kabupaten Temanggung Berbasis Android dengan Global Positioning System ( GPS )', 2(1), pp. 29-40.

[23] Sosa, J., Roy, A. and Bautista, Adriana, 2015 (2015) 'MICRO , SMALL AND MEDIUM ENTERPRISES AND SOCIAL NETWORKS IN TOURISM INDUSTRY IN MANZANILLO ', III(1), pp. 90-105. doi: 10.20472/BM.2015.3.1.006.

[24] Stuart Read, Nicholas Dew, Saras D. Sarasvathy, Michael Song, R. W. (2009) 'arketing Under Uncertainty: The Logic of an Effectual Approach', Journal of Marketing, 73(3), pp. 1-18. Available at: https://doi.org/10.1509/jmkg.73.3.1.

[25] Tourism Industry Aotearoa (2017) 'Tourism - a partnership between the private sector and Government Brief to the Minister of Tourism Table of Contents', (November).

[26] Varraa, L. et al. (2012) 'No Title', Procedia - Social and Behavioral Sciences 41 (, 41(41), pp. 375-385. Available at: https://core.ac.uk/download/pdf/82495630.pdf. 